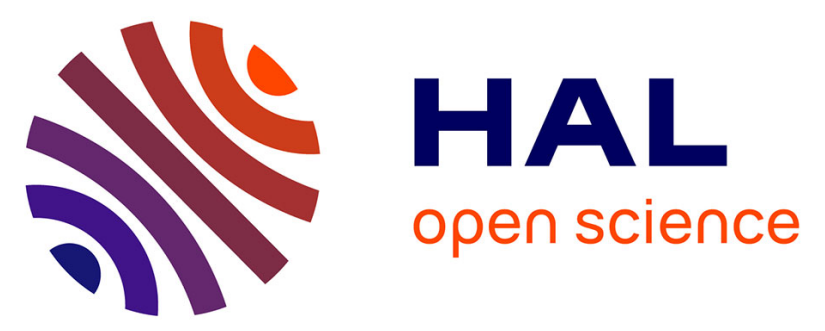

\title{
Diatom valve distribution and sedimentary fatty acid composition in Larsen Bay, Eastern Antarctica Peninsula
}

E. Sañé, E. Isla, Audrey M Pruski, M. A. Bárcena, G. Vétion, D. J. Demaster

\section{To cite this version:}

E. Sañé, E. Isla, Audrey M Pruski, M. A. Bárcena, G. Vétion, et al.. Diatom valve distribution and sedimentary fatty acid composition in Larsen Bay, Eastern Antarctica Peninsula. Continental Shelf Research, 2011, 31 (11), pp.1161-1168. 10.1016/j.csr.2011.04.002 . hal-02908657

\section{HAL Id: hal-02908657 \\ https://hal.sorbonne-universite.fr/hal-02908657}

Submitted on 29 Jul 2020

HAL is a multi-disciplinary open access archive for the deposit and dissemination of scientific research documents, whether they are published or not. The documents may come from teaching and research institutions in France or abroad, or from public or private research centers.
L'archive ouverte pluridisciplinaire HAL, est destinée au dépôt et à la diffusion de documents scientifiques de niveau recherche, publiés ou non, émanant des établissements d'enseignement et de recherche français ou étrangers, des laboratoires publics ou privés. 


\section{Author's Accepted Manuscript}

Diatom valve distribution and sedimentary fatty acid composition in the Larsen A and B bays, Eastern Antarctica Peninsula

E. Sañé, E. Isla, A.M. Pruski, M.A. Bárcena, G. Vétion, D. DeMaster

PII: S0278-4343(11)00129-4

DOI: doi:10.1016/j.csr.2011.04.002

Reference: CSR 2360

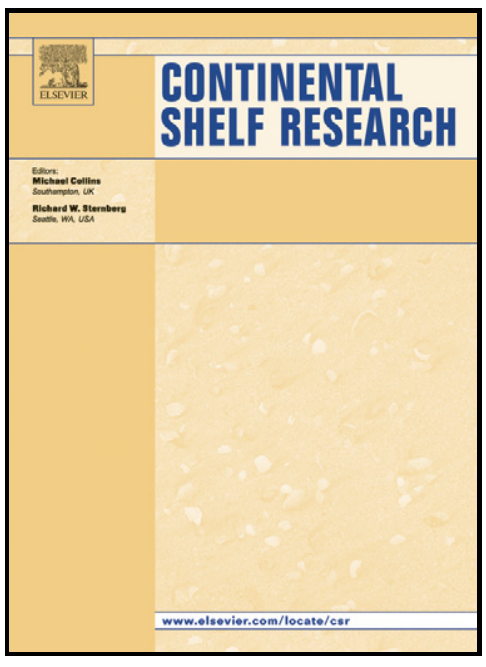

www.elsevier.com/locate/csr

To appear in: $\quad$ Continental Shelf Research

Received date: 18 March 2010

Revised date: $\quad 10$ March 2011

Accepted date: 5 April 2011

Cite this article as: E. Sañé, E. Isla, A.M. Pruski, M.A. Bárcena, G. Vétion and D. DeMaster, Diatom valve distribution and sedimentary fatty acid composition in the Larsen A and B bays, Eastern Antarctica Peninsula, Continental Shelf Research, doi:10.1016/j.csr.2011.04.002

This is a PDF file of an unedited manuscript that has been accepted for publication. As a service to our customers we are providing this early version of the manuscript. The manuscript will undergo copyediting, typesetting, and review of the resulting galley proof before it is published in its final citable form. Please note that during the production process errors may be discovered which could affect the content, and all legal disclaimers that apply to the journal pertain. 


\title{
Diatom valve distribution and sedimentary fatty acid composition in the Larsen A and B bays, Eastern Antarctica Peninsula.
}

\author{
${ }^{1}$ Sañé, E., I'Ila, E., ${ }^{2,3}$ Pruski, A.M., ${ }^{4}$ Bárcena, M.A., ${ }^{2,3}$ Vétion, G., ${ }^{5}$ DeMaster, D. \\ ${ }^{1}$ Institut de Ciències del Mar-CSIC, Passeig Maritim de la Barceloneta 37-49, Barcelona E-08039, Spain \\ ${ }^{2}$ UPMC Univ Paris 06, FRE 3350, LECOB, Observatoire Océanologique, F-66651 Banyuls/mer, France \\ ${ }^{3}$ CNRS, FRE 3350, LECOB, Observatoire Océanologique, F-66651, Banyuls/mer, France \\ ${ }^{3}$ Depto. de Geología y Paleontología, Facultad de Ciencias, Universidad de Salamanca 37008 Salamanca, Spain \\ ${ }^{5}$ Department of Marine, Earth and Atmospheric Sciences, North Carolina State University, Raleigh, NC 27695-8208, \\ U.S.A.
}

\begin{abstract}
During austral summer 2006-2007, five sediment cores were recovered from the Eastern Antarctic Peninsula (EAP) continental shelf. Microscopic observations and sediment fatty acid (FA) composition analyses were carried out to investigate whether the drastic changes at the sea surface in EAP may be reflected in the sedimentary record. A sharp decrease in the number of diatom valves was observed below $2 \mathrm{~cm}$ depth. This evident difference between the upper 2 $\mathrm{cm}$ of sediment and the deeper part of the sediment column was attributed to the drastic change in the upper water column conditions after the ice shelf collapses, which allowed the arrival of phytoplankton debris and fresh organic matter to the seafloor in EAP. The presence of bacterial, zooplankton- and detrital-related FA throughout EAP cores suggests that there has been an input of older, more refractory organic matter into the region, presumably by lateral transport, before Larsen ice shelves disintegration.
\end{abstract}

\section{Introduction}

In the last 60 years atmospheric and oceanic temperatures have risen (Vaughan et al., 2001; Gille, 2002), leading to an increase of glacier retreat in the Antarctic Peninsula (Cook et al., 2005). In 1995, $4200 \mathrm{Km}^{2}$ of the Larsen A ice shelf collapsed, whereas $3200 \mathrm{Km}^{2}$ of the Larsen B ice shelf disintegrated in 33 days in 2002 (Rott et al., 1996; Domack et al., 2005). These events drastically modified the local conditions at the sea surface, relatively constant for hundreds of years (Domack et al., 2005). The ice shelf collapses enabled primary production in the recently open space (Bertolin and Schloss, 2009) to develop a flux of fresh organic debris to the seabed. Thus, studying the sediments organic matter (OM) content beneath extinct ice shelves may reveal how changes at the euphotic zone impact the benthic realm.

Sediment microscopic observations of phytoplankton provide information about the origin of the OM present in the sediment (Reuss and Poulsen, 2002). Diatoms, radiolaria, siliceous sponges, and silicoflagellates contribute with their siliceous skeleton to the biogenic silica flux to the seafloor and the consequent accumulation of this biogenic constituent in the sediment column (Abelmann and Gersonde, 1991; DeMaster, 2002). Diatom valves and sponge spicules represent the principal sources of biogenic silica in sediments (Rützler and Maclntyre, 1978; Bavestrello et al., 1996) and, in the Southern Ocean, diatoms represent $40 \%$ of the total primary production (Cortese and Gersonde, 2007), with high biomasses in Antarctic coastal regions (Wright and van den Enden, 2000; Arrigo et al., 2008; Beans et al., 2008). In the water 
48 column, diatom valves are subjected to grazing (Crosta, 2009), advection and 49 dissolution (Buffen et al., 2007), nevertheless their frustules are well-preserved in 50 sediments (Tsoy et al., 2009). Fragilariopsis kerguelensis is the most abundant diatom 51 species in Antarctic surface sediments (Cortese and Gersonde, 2007) and in this study 52 has been considered as an indicator of open-water conditions (Crosta et al., 2005; 53 Roberts et al., 2007). The diatom valves of sea-ice related taxa (Fragilariopsis curta, F. 54 cylindrus, F. obliquecostata and F. sublinearis), auxospores of Thalassiosira antarctica, 55 as well as the resting spores (RS) of genus Chaetoceros have been treated as sea-ice 56 related species (Armand et al., 2005). These sea-ice related taxa are present within the 57 Sea Ice Zone southward of the Polar Front, living within, on or under the sea ice 58 (Armand et al., 2005). Thalassiosira antarctica is a sea-ice related species (Garrison et 59 al., 1987; Garrison, 1991) indicative of seasonally varying sea-ice conditions, which 60 shows maximum abundance near the ice shelf edge, but requires cold open water to 61 dwell (Pike et al., 2008) and Chaetoceros RS abundance reflects episodes of high 62 primary production (Donegan and Schrader, 1982; Leventer, 1991; Sancetta et al., 63 1992; Karpuz and Jansen, 1992).

64 Fatty acids (FA), aliphatic hydrocarbon chains with a carboxylic group at one extremity, 65 are synthesised in the cytosol. In marine organisms FA are predominantly found in 66 energetic reserves which consist of triacylglycerols and wax esters, as well as in the 67 phospholipids of the membrane lipid bilayer (Ding and Sun, 2005). A partial and 68 selective degradation of FA occurs in the water column and in the sediment (Sun et al., 69 1997; Wakeham et al., 1997) and is particularly intense at the sediment-water interface 70 (Laureillard et al., 1997). However, FA occurrence in the sediment column has been 71 broadly studied (Farrington and Quinn, 1973; Perry et al., 1979; Volkman et al., 1980;

72 Venkatesan, 1988; Canuel and Martens, 1996; Sun and Wakeham, 1994; Cripps and 73 Clarke, 1998). The presence of FA in Antarctic sediments has been ascribed to marine 74 primary and secondary production due to the absence of terrestrial inputs (Venkatesan 75 and Kaplan, 1987; Cripps, 1995; Cripps and Clarke, 1998). Diatoms, dinoflagellates, 76 bacteria and zooplankton organisms are characterized by different FA and through 77 their signature is possible to obtain information about the potential sources of the 78 sedimentary organic matter found in the sea floor (Budge and Parrish, 1998; Camacho79 Ibar et al., 2003). The specificity of FA for particular organisms together with the 80 different labilities of FA depending on their chemical structure (Haddad et al., 1992; 81 Canuel and Martens, 1996; Sun and Wakeham, 1994; Camacho-Ibar et al., 2003; Lü et 82 al., 2010), make FA analysis a useful tool to investigate on OM sources and quality. 
83 Microscopic counts of diatom valves and sediment FA composition analysis have been

84 carried out in the sedimentary record to verify the presence of temporal changes in the

85 FA and diatom valve signatures related to Larsen A and B ice shelves collapse.

86

87 2. Methods

882.1 Sediment collection and preparation

89 Sediment samples were collected during the Antarctic expedition ANT-XXIII/8 off the

90 Eastern coast of the Antarctic Peninsula (EAP) (Fig. 1) using a multi-corer with

91 polycarbonate core barrels of $10 \mathrm{~cm}$ of diameter (Barnett et al., 1984). Sediments were

92 sampled at 5 stations, namely Larsen B South (LBS), Larsen B West (LBW), Larsen B

93 Central (LBC), Larsen B North (LBN) and Larsen A (LA) (Fig.1). After recovery,

94 sediment cores were sliced onboard in slices $0.5 \mathrm{~cm}$ thick from 0 to $9 \mathrm{~cm}$ depth. LA

95 core was only $7.5 \mathrm{~cm}$ long. Subsamples were immediately frozen at $-20^{\circ} \mathrm{C}$. Sediment

96 samples were freeze-dried $\left(P=0.1 \mathrm{mbar}\right.$ and $\left.\mathrm{T}=-80^{\circ} \mathrm{C}\right)$ for 24 hours before laboratory

97 analyses and microscopic observations.

98

99

2.2 Diatom slides preparation and microscopic observation

100 Sediment samples were prepared according to the standard randomly distributed

101 microfossils method. Due to the high abundance of diatom valves, it was not necessary

102 to disaggregate sediment with sodium pyrophosphate. Hydrochloric acid ( $\mathrm{HCl})$ and

103 hydrogen peroxide $\left(\mathrm{H}_{2} \mathrm{O}_{2}\right)$ were added to a known weight of dry sediment to attack

104 carbonates and OM. Sediment was rinsed several times with bi-distilled water, slides

105 were mounted and diatom valve counts were performed at 1000 magnification using a

106 Leica DMLB with phase-contrast illumination. Counts were carried out on permanent

107 slides of acid-cleaned material (Permount mounting medium). Schrader and Gersonde

108 (1978) recommendations were followed for the counting of microfossil valves.

109 Depending on diatoms abundance, several traverses across each cover slip were

110 examined. A minimum of 350 valves were counted for each sample, when possible.

111 Moreover, a counting of at least 100 valves of non-dominant taxa per sample was

112 performed. Valves of sea-ice taxa and F. kerguelensis, auxospores of $T$. antarctica

113 were identified together with Chaetoceros RS.

114 Diatom valve inventories were calculated by summing the product of the number of

115 diatom valves, the depth interval (slice thickness) and the wet bulk density of each sub

116 sample. Inventories are expressed in number of diatom valves per square centimeter

117 (valves $\mathrm{cm}^{-2}$ ). Diatom valve fluxes were calculated from diatom valve inventories and

118 expressed in number of diatom valves per square centimeter per year (valves $\mathrm{cm}^{-2} \mathrm{yr}^{-}$

$119{ }^{1}$ ). Fluxes were calculated by dividing diatom valve inventories by the number of years 
120 of deposition, assuming no differences in the flux of diatoms to the seabed among

121 years.

122

123

\subsection{Fatty acid extraction}

124 Fatty acids were extracted through a one step transesterification process adapted from 125 Lewis et al., (2000) and Indarti et al. (2005) according to the recommendations of 126 Christie (2003). The analytical protocol is detailed in Nahon et al (2010). Approximately $1272 \mathrm{~g}$ of dried sediment were extracted in $8 \mathrm{ml}$ of a cold solution of methanol, $98 \%$ 128 sulphuric acid and chloroform in the presence of butyl hydroxytoluene (BHT), an 129 antioxidant at a concentration of $50 \mathrm{mg} \mathrm{l}^{-1}$ (Christie, 2003) The ratio of methanol to 130 chloroform to sulphuric acid in the solvent extraction was 1.7:2:0.3 v/v/v. $20 \mu \mathrm{l}$ of the 131 internal standard C19:0 (nonadecanoic acid) $\left(1 \mathrm{mg} \mathrm{ml}^{-1}\right)$ were added and the samples 132 were placed in a preheated oven at $90^{\circ} \mathrm{C}$ for 90 minutes. With this procedure lipids 133 were extracted and the released fatty acids were directly methylated in fatty acid 134 methyl esters (FAME). Ultra pure water $(2 \mathrm{ml})$ was added to each sample to partition 135 the extract in two phases. Following centrifugation ( 5 minutes at $1500 \mathrm{rpm}$ and $4^{\circ} \mathrm{C}$ ), 136 the inferior chloroform phase was recovered. A second extraction was made with a 137 solution of hexane and chloroform (4:1 v/v) and, after centrifugation (5 minutes at 1500 $138 \mathrm{rpm}$ and $4^{\circ} \mathrm{C}$ ), the superior phase was recovered and added to the first organic phase. 139 This procedure was repeated twice. The organic phases were pooled and cleaned with 140 a cold solution of potassium carbonate (2\%) and after centrifugation (5 minutes at 1500 $141 \mathrm{rpm}$ and $4^{\circ} \mathrm{C}$ ) 6 to $9 \mathrm{ml}$ of the organic phase were recovered and an aliquot was 142 evaporated to dryness in a rotary evaporator (Savant Speed Vac system) at room 143 temperature. FAME were recovered in $75 \mu \mathrm{l}$ of pure hexane prior to analysis. Fatty 144 acids as methyl esters were analysed using a Varian 3900 gas chromatograph (GC) 145 coupled to a Saturn 2100T ion-trap mass spectrometer (MS). A Varian Factor Four 146 capillary column WAX-ms was used. The column had a length of $30 \mathrm{~m}$ and an internal 147 diameter of $0.25 \mathrm{~mm}$; film thickness was $0.25 \mu \mathrm{m}$. The flow was constant with a velocity 148 of $1 \mathrm{ml} / \mathrm{min}$. The column oven stabilization time was $0.30 \mathrm{~min}$, the injector temperature 149 was $260^{\circ} \mathrm{C}$ and the volume injected was $1 \mu \mathrm{l}$. The use of known standards as 150 reference (Supelco 37, PUFA $n^{\circ} 1$ and $n^{\circ} 3$ ) allowed the identification of 22 individual 151 fatty acids.

152

153 In order to present the dataset in a comprehensible form, fatty acids were grouped 154 according to their chemical structure in:

155 (1) Polyunsaturated fatty acids (PUFA): compounds with two or more unsaturated 156 bonds. 
(2) Monounsaturated fatty acids (MUFA): compounds with one unsaturation.

(3) Mid chain fatty acids (MC-FA): chain length $\leq C_{20}$.

(4) Long chain fatty acids (LC-FA): chain length $\mathrm{C}_{21}-\mathrm{C}_{26}$.

160

161

\section{Results}

162

163

\subsection{Microscopic observation of diatom valves}

164 The total abundance of diatom valves in the upper $0.5 \mathrm{~cm}$ of sediment ranged from $165 \sim 1.3 \times 10^{6}$ valves $\mathrm{g}^{-1}$ (station LBS) to $\sim 18.4 \times 10^{6}$ valves $\mathrm{g}^{-1}$ (station LBC) (Fig. 2). Diatom

166 valve abundances decreased with depth and, in the four Larsen $B$ cores, they were 167 negligible below $2 \mathrm{~cm}$ depth (Fig. 2).

168 Diatom valve inventories varied between $\sim 4.7 \times 10^{6}$ valves $\mathrm{cm}^{-2}$ (station LBW) and $\sim 35.3$ $169 \times 10^{6}$ valves $\mathrm{cm}^{-2}$ (station LBC), whereas diatom valve fluxes varied between $\sim 9.4 \times 10^{5}$ 170 valves $\mathrm{cm}^{-2} \mathrm{yr}^{-1}$ (station LBW) and $\sim 70.5 \times 10^{5}$ valves $\mathrm{cm}^{-2} \mathrm{yr}^{-1}$ (station LBC) (Table 1).

171 As regards diatoms composition, valves of sea-ice taxa, auxospores of $T$. antarctica 172 and Chaetoceros RS were found in all stations. Mean relative abundances of sea-ice 173 taxa and Chaetoceros RS in the upper $0.5 \mathrm{~cm}$ of sediment of the five EAP cores were $174 \sim 40 \%$ and $\sim 52 \%$, respectively, and decreased with depth (Fig. 3). The mean relative 175 abundance of the auxospores of $T$. antarctica was $\sim 1 \%$ and didn't change with depth 176 (Fig. 3). 3.2 Fatty acid composition

179 Diatom indicators 14:0 and 16:1(n-7) (Nichols et al., 1986; Nichols et al., 1993; 180 Dunstan et al., 1994) were present in all the stations (Fig. 4). In the superficial 181 sediment (upper $0.5 \mathrm{~cm}$ ), the concentration of FA 14:0 varied between $\sim 4 \mathrm{\mu g} \mathrm{g}^{-1}$ (LBA) 182 and $\sim 8 \mu \mathrm{g} \mathrm{g}^{-1}$ (LBS), whereas that of FA 16:1(n-7) varied between $\sim 3 \mu \mathrm{g} \mathrm{g}^{-1}$ (LBA) and $183 \sim 9 \mu \mathrm{g} \mathrm{g}^{-1}$ (LBC). A decrease in the concentration of diatom indicators with depth was 184 evident in cores LBS, LBC and LBN (Fig. 4). Dinoflagellate indicators 16:0 and 18:1(n185 9) cis (Dalsgaard et al., 2003; Søreide et al., 2008) and zooplankton indicators 20:1(n186 9) and 22:1(n-9) (Falk-Petersen et al., 1999) were present at the five stations (Fig. 4). 187 The superficial concentration of dinoflagellate indicator FA 16:0 varied between $\sim 23 \mu \mathrm{g}$ $188 \mathrm{~g}^{-1}$ (LBA) and $\sim 42 \mu \mathrm{g} \mathrm{g}^{-1}$ (LBN), whereas that of dinoflagellate indicator FA 18:1(n-9) cis 189 varied between $\sim 18 \mu^{-1}$ (LBA) and $\sim 52 \mu \mathrm{g} \mathrm{g}^{-1}$ (LBC). As regards zooplankton 190 indicators, the superficial concentration of 20:1(n-9) varied between $\sim 2 \mathrm{\mu g} \mathrm{g}^{-1}$ (LBA) 191 and $\sim 4 \mu \mathrm{g} \mathrm{g}^{-1}$ (LBC and LBN), and that of FA 22:1(n-9) between $\sim 3 \mu \mathrm{g} \mathrm{g}{ }^{-1}$ (LBA) and $\sim 6$ $192 \mathrm{\mu g} \mathrm{g}^{-1}$ (LBS). Odd bacterial FA 11:0, 13:0 and 15:0 (Lee, 1992; Dalsgaard et al., 2003 193 and references therein) were present in all the stations (Fig. 4). In the superficial 
194 sediment, the concentration of FA 11:0 was $\sim 0.1-0.2 \mu \mathrm{g} \mathrm{g}^{-1}$, that of FA 13:0 was $\sim 0.2$ -

$1950.4{\mu g ~ g^{-1}}$ and that of FA 15:0 was $\sim 0.6-1.1 \mu \mathrm{g} \mathrm{g}^{-1}$.

196 PUFA represented a small component of the total FA pool. Only one PUFA was 197 present at the five stations, $18: 2(n-6)$ cis. The concentration of $18: 2(n-6)$ cis in the 198 superficial sediment varied between $\sim 1 \mu \mathrm{g} \mathrm{g}^{-1}$ (LA) and $\sim 2 \mu \mathrm{g} \mathrm{g}^{-1}$ (LBC) (Fig. 5). Four 199 MUFA, namely 16:1(n-7), 18:1(n-9)cis, 20:1(n-9) and 22:1(n-9), were found in the five 200 stations, whereas $24: 1(n-9)$ only occurred at LBS. The total concentration of MUFA in 201 the superficial sediment varied between $\sim 26 \mu \mathrm{g} \mathrm{g}^{-1}$ (LA) $\sim 70 \mu \mathrm{g} \mathrm{g}^{-1}$ (LBC) (Fig. 5). MC202 FA 8:0, 10:0, 11:0, 12:0, 13:0, 14:0, 15:0, 16:0, 18:0 and 20:0 were present in the five 203 cores. In the superficial sediment, the total concentration of MC-FA varied between $\sim 68$ $204 \mu g^{-1}$ (LA) 101 $\mu^{-1}$ (LBW) (Fig. 5). Among the LC-FA, 22:0 and 24:0 were the only 205 compounds present at the five stations. 21:0 only occurred at LBS and LBN and 26:0 at 206 LBS. The total concentration of LC-FA in the superficial sediment varied between $\sim 0.5$ $207 \mu \mathrm{g} \mathrm{g}^{-1}$ (LA) and $\sim 1.4 \mu \mathrm{g} \mathrm{g}^{-1}$ (LBC) (Fig. 5).

208

209

\section{Discussion}

210 FA and diatom valves were assessed in the continental shelf of EAP to find whether these indicators can reflect changes in the sediment column derived from the presence and recent disintegration of the Larsen A and B ice shelves.

213 Radionuclides $\left({ }^{210} \mathrm{~Pb}\right.$ and $\left.{ }^{14} \mathrm{C}\right)$ data were used to establish sediment chronologies and

214 determine which layer in the EAP sediment column could correspond to the time when 215 Larsen ice shelf collapses occurred (Isla et al., unpublished results). Sediment cores 216 were obtained only a decade after Larsen A and B ice shelf collapsed and, given the $217{ }^{210} \mathrm{~Pb}$ half life $(22.3 \mathrm{y})$, steady state conditions were not yet attained in this region. The 218 analysis of ${ }^{14} \mathrm{C}$ in sediment core LBW showed that the SAR was on the order of 0.04 $219 \mathrm{~cm} \mathrm{y}^{-1}$ (Isla et al., unpublished results). This low sedimentation rate suggested that in 220 EAP, accumulation (advection) is still negligible and diffusion is the main responsible 221 for particle motion in the sediment cores of this region. The rather low sediment 222 accumulation in EAP led us to argue that the layer which corresponds to the time 223 period after the ice shelf collapses in Larsen A and Larsen B is, at most, only few 224 millimetres thick. These low accumulation rates hamper distinguishing differences 225 between Larsen A and B profiles (Fig. 2, 4 and 5), despite the 7-year difference in the 226 respective ice shelf collapses in the two bays. The significant correlation between the 227 excess ${ }^{210} \mathrm{~Pb}$ activity, diatom valves abundance and pigment concentration profiles 228 (Fig. 6, see also Sañé et al., 2011) provided evidence to suggest that pigments and 229 diatom valves were deposited in EAP only after the ice shelves collapsed and primary 230 production started developing (Bertolin and Schloss, 2009; Isla et al., unpublished 
231 results). Then, the biogenic material from the upper millimetres has been redistributed

232 along the upper $2 \mathrm{~cm}$ layer during the last decade (Fig. 6) and we assume that all the

233 organic matter present below $2 \mathrm{~cm}$ depth reached EAP region though lateral transport

234 before the collapse of Larsen ice shelves.

235 Based on the fact that primary production started in the Larsen bays only $\sim 10$ years

236 ago, after ice shelves collapsed (Bertolin and Schloss, 2009), we hypothesized that

237 higher diatom valve abundances and FA concentrations should be found at the top of

238 the sediment cores than below $2 \mathrm{~cm}$ depth. Furthermore, we also hypothesised that

239 differences in FA concentrations related to organic matter lability would be found

240 between the upper $2 \mathrm{~cm}$ of sediment (more labile), where the biogenic matter

241 deposited after ice shelf collapses (Isla et al., unpublished results; Sañé et al., 2011)

242 and the deeper part of the sediment cores (more refractory).

243

244 4.1 Diatom signature

245 Our results on diatom valves abundance (Fig. 2) confirm that primary production and

246 the vertical flux of organic matter to the sea floor are negligible under ice shelves

247 (Littlepage and Pearse, 1962) and that diatom valve abundances augmented after

248 Larsen ice shelf collapses (Buffen et al., 2007). Furthermore, the absence of diatom

249 valves below the upper $2 \mathrm{~cm}$ layer in EAP sediment suggests that the lateral transport

250 of diatom valves into the region is negligible. The diatom valves present in the upper 2

$251 \mathrm{~cm}$ of sediment have been recently produced and vertically transported through the

252 water column. Given the relatively short period of accumulation of diatom valves in

253 EAP it is rather unlikely that diatom valves in EAP had undergone vigorous dissolution

254 up to the degree that they are not visible towards the base of the core. Thus, valve

255 profiles corroborate that diatoms arrived to EAP sea floor only after Larsen A and B ice

256 shelf collapses.

257 No significant differences in diatom valve fluxes were found between EAP region and

258 two stations off the Northern Antarctic Peninsula which have not been covered by ice

259 shelf for at least $1 \mathrm{kyr}$ (Ingólfsson et al., 1998). In the case of Larsen B cores, diatom

260 valve fluxes were calculated dividing diatom valve inventories from 0 to $5 \mathrm{~cm}$ depth by

2615 years, which is the time span between the ice shelf collapse and the sampling

262 expedition. Based on the excess ${ }^{210} \mathrm{~Pb}$ activity and the pigment profiles (Fig. 6 and

263 Sañé et al., 2011), diatom fluxes for EAP were calculated using diatom valve

264 inventories from 0 to $5 \mathrm{~cm}$ depth to assure including diatom valves deposited after the

265 ice shelf collapse. In the case of the two stations off the Northern Antarctic Peninsula,

266 the diatom valves inventory of the $11 \mathrm{~cm}$ long sediment core corresponding to the

267 Elephant Island station was divided by 36 years (based on a sediment accumulation 
268 rate of $3.02 \mathrm{~mm} \mathrm{y}^{-1}$; Isla et al., unpublished results), whereas the diatom valves 269 inventory of the $11 \mathrm{~cm}$ long sediment core corresponding to the South Shetland Island 270 station was divided by 58 years (based on a sediment accumulation rate of $1.90 \mathrm{~mm} \mathrm{y}$

$271{ }^{1}$; Isla et al., unpublished results). The presence of icebergs in EAP region, related to 272 the recent Larsen A and B ice shelf collapses, should reduce the available area for 273 phytoplankton blooms to develop, and, consequently, primary production in this region 274 (Arrigo et al., 2002; Arrigo and van Dijken, 2003). Nevertheless, similarities in diatom 275 valve fluxes between EAP region and the two stations off the Northern Antarctic 276 Peninsula may be related to the rather moderate to low primary production off the 277 South Shetland and Elephant Islands (Bodungen et al., 1986; Holm-Hansen and 278 Mitchell, 1991; Holm-Hansen et al., 1997).

279 The absence of Fragilariopsis kerguelensis in EAP is consistent with the absence of 280 open water conditions (Crosta et al., 2005) until 1995 and 2002 in Larsen A and B, 281 respectively, whereas the high percentage of sea-ice related taxa implies that this 282 region is not experiencing true seasonal open-water conditions yet (Fig. 3).

283

284 4.2 Fatty acid signature

285 Changes in the FA profiles between the parts of the sediment column corresponding to 286 the pre- and the post- ice shelves collapse were less evident than those observed for 287 the diatom valves signature (Fig. 4, 5), probably due to FA lability. FA are characterized 288 by different labilities depending on their chemical structure. FA with a high number of 289 unsaturations or polyunsaturated FA (PUFA) represent the most labile group of FA 290 (Haddad et al., 1992; Sun and Wakeham, 1994). The low concentration of PUFA (Fig. 291 5) and the absence of PUFA diatom indicators, such as $16: 2(n-4)$ and $16: 3(n-4)$ 292 (Volkman et al., 1989; Wakeham, 1995), even in the upper $2 \mathrm{~cm}$ of the sediment 293 column where high abundances of diatom valves were found, suggests that PUFA 294 were previously degraded in the water column or/and after deposition onto the seabed 295 (Smith et al., 1983; Wakeham et al., 1997; Budge and Parrish, 1998; Grossi et al., 296 2003; Hu et al., 2006). Differently from PUFA diatom indicators, MUFA and MC-FA 297 diatom indicators, like FA 16:1(n-7) and FA 14:0, were found in EAP and their 298 concentrations decreased with depth in the five cores (Fig. 4), reflecting changes in the 299 water column related to Larsen ice shelves disintegration. Differences between FA 300 profiles may be related to the lower lability of MUFA and MC-FA in relation to PUFA 301 (Haddad et al., 1992). The low concentration of FA 14:0 and FA 16:1(n-7) below $2 \mathrm{~cm}$ 302 depth (Fig. 4) suggested that these fatty acids which originate from diatoms did not 303 accumulate in EAP sediment column by lateral transport before the collapse of Larsen 304 ice shelves. 
305 On the contrary, no temporal changes were observed in the profiles of dinoflagellate 306 indicators MUFA 18:1(n-9) cis and MC-FA 16:0, and in the profiles of zooplankton 307 indicators, MUFA 20:1(n-9) and 22:1(n-9) (Fig. 4). MUFA 18:1(n-9) cis has not only 308 been associated to flagellate-derived material (Søreide et al., 2008), but also to detrital 309 material (Fahl and Kattner, 1993). Its presence throughout EAP cores, like the 310 presence of zooplankton indicators MUFA 20:1(n-9) and 22:1(n-9), could suggest the 311 input of older more refractory $\mathrm{OM}$ into the region presumably by lateral transport before 312 ice shelves collapses. Dinoflagellate indicators FA 18:1(n-9) cis and FA 16:0 and 313 zooplankton indicators FA 20:1(n-9) and FA 22:1(n-9) have similar labilities to diatom 314 indicators FA 14:0 and FA 16:1(n-7). Therefore, the low concentration of FA 14:0 and 315 FA 16:1(n-7) below $2 \mathrm{~cm}$ depth (Fig. 4) is independent from the lability of these two 316 fatty acids and suggested that they did not reach Larsen region before ice shelf 317 collapses through lateral transport.

318 The absence of bacterial indicators like hydroxylated FA and 18:1(n-7) (Perry et al, 319 1979) or like iso- and anteiso-FA (Parkers and Taylor, 1983; Kaneda, 1991) suggests a 320 low bacterial activity; the only bacterial indicators present in EAP, MC-FA with an odd 321 number of carbon atoms (Lee, 1992; Dalsgaard et al., 2003 and references therein), 322 may also have accumulated in this region before ice shelf collapses by lateral 323 transport. The idea that MUFA and MC-FA could have been laterally transported to 324 EAP is supported by previous studies on benthos under ice shelves. Even if primary 325 production below ice shelves is negligible (Littlepage and Pearse, 1962), the few 326 studies on benthos below ice shelves revealed that a lateral flux of organic matter 327 maintained benthic assemblages of suspension feeders at different distances from the 328 ice shelf edge (Dayton and Oliver, 1977; Lipps et al.,1979; Riddle et al., 2007).

329 Long-chain saturated FA, LC-FA, are mainly of terrestrial origin and usually considered 330 more resistant to degradation than planktonic FA (Canuel and Martens, 1996; 331 Camacho-Ibar et al., 2003). Due to their low lability (Haddad et al., 1992; Sun and 332 Wakeham, 1994), we expected to find evidence of the lateral transport in the study 333 area also of this group of FA. Terrestrial inputs are absent in the study area, therefore, 334 in spite of their low lability, only a low concentration of LC-FA was found in our 335 sediment samples (Fig. 5) and the LC-FA found in EAP may be the result of MUFA 336 chain lengthening (Nichols et al., 1986).

\subsection{Summary}

339 Diatom valve abundance in sediment cores collected from the continental shelf of the 340 Larsen A and B bays provided evidence to suggest that diatom valves were deposited 341 only after Larsen ice shelves collapse. Temporal changes in the FA signature were less 
evident than those observed for the diatom valves signature. In spite of the presence of diatom valves in the upper $2 \mathrm{~cm}$ of sediment, some diatom indicators like unsaturated FA $16: 2(n-4)$ and 16:3(n-4) were not found in EAP cores, probably due to their high lability. The presence of some bacterial- and zooplankton- related MUFA and MC-FA suggests that there has been an input of refractory organic matter into the region, presumably by lateral transport, before Larsen ice shelves collapse.

\section{References}

Abelmann, A., and Gersonde, R., 1991, Biosiliceous particle flux in the Southern Ocean: Marine 352 Chemistry 35, 503-536.

Arrigo, K.R., van Dijken, G.L., Ainley, D.G., Fahnestock, M.A., Markus, T., 2002. Ecological impact of a large Antarctic iceberg. Geophys. Res. Lett. 29, 1-4.

Arrigo, K.R. and van Dijken, G.L., 2003. Impact of iceberg C-19 on Ross Sea primary production. Geophys. Res. Lett. 30, 1-4.

Arrigo, K.R., van Dijken, G.L., Bushinsky, E., 2008. Primary production in the Southern Ocean, 1997-2006. Journal of Geophysical Research 113, C08004.

Armand, L., Crosta, X., Romero, O., Pichon, J.J., 2005. The biogeography of major diatom taxa in Southern Ocean sediments. 1. Sea ice related species. Palaeogeography, Palaeoclimatology, Palaeoecology 223, 93-126.

Barnett, P.R.O., Watson, J., Connelly, D., 1984. A multiple corer for taking virtually undisturbed samples from shelf, bathyal and abyssal sediments. Oceanol. Acta 7, 399-408.

Bavestrello, G., Cattaneo-Vietti, R., Cerrano, C., Cerutti, S., Sará, M., 1996. Contribution of Sponge Spicules to the Composition of Biogenic Silica in the Ligurian Sea. Mar. Ecol. 17, 41-50.

Beans, C., Hecq,J.H., Koubbi, P.,Vallet, C.,Wright, S., Goffart, A., 2008. A study of the diatomdominated microplankton summer assemblages in coastal waters from Terre Adélie to the Mertz Glacier, East Antarctica (1391E-1451E). Polar Biol. 31, 1101-1117.

Bertolin, M.L. and Schloss, I.R., 2009. Phytoplankton production after the collapse of the Larsen A Ice Shelf, Antarctica. Polar Biol. 32, 1435-1446.

Bodungen, B.V., Smetacek, V.S., Tilzer, M.M., Zeitzschel, B., 1986. Primary production and sedimentation during spring in the Antarctic Peninsula region. Deep-Sea Res. 33, 177-194.

Budge, S.M. and Parrish, C.C., 1998. Lipid biogeochemistry of plankton, settling matter and sediments in Trinity Bay, Newfoundland. II. Fatty acids. Org. Geochem. 29, 1547-1559.

Buffen, A., Leventer, A., Rubin, A., Hutchins, T., 2007. Diatom assemblages in surface sediments of the northwestern Weddell Sea, Antarctic Peninsula. Mar. Micropal. 62, 7-30.

Camacho-lbar, V.F., Aveytua-Alcázar, L., Carriquiry, J.D., 2003. Fatty acid reactivities in sediment cores from the northern Gulf of California. Organic Geochemistry 34, 425-439.

Canuel, E.A. and Martens, C.S., 1996. Reactivity of recently deposited organic matter: degradation of lipid compounds near the sediment-water interface. Geochim. Cosmochim. Acta 60, 1793-1806.

Christie, W.W. Lipid Analysis: Isolation, Separation, Identification and Structural Analysis of Lipids, 3rd Oily Press, Bridgwater, UK (2003) 207 pp. 
Cook, A.J., Fox, A.J., Vaughan, D.G., Ferrigno, J.G., 2005. Retreating Glacier Fronts on the Antarctic Peninsula over the Past Half-Century. Science 308, 541-544.

Cortese, G. and Gersonde, R. 2007. Morphometric variability in the diatom Fragilariopsis kerguelensis : implications for Southern Ocean paleoceanography. Earth and Planetary Science Letters $257,526-544$.

Cripps, G.C., 1995. The occurrence of monounsaturated n- $\mathrm{C}_{21}$ and polyunsaturated $\mathrm{C}_{25}$ sedimentary hydrocarbons in the lipids of Antarctic marine organisms. Polar Biol. 15, 253-259.

Cripps, G.C. and Clarke, A., 1998. Seasonal variation in the biochemical composition of the particulate material collected by sediment traps at Signy Island, Antarctica. Polar Biol. 20, 414423.

Crosta, X., 2009. Holocene size variations in two diatoms species, East Antarctica: productivity vs environmental conditions. Deep Sea Res. I 56, 1983-1993.

Crosta, X., Romero, O., Armand, L.K., Pichon, J.J., 2005. The biogeography of major diatom taxa in Southern Ocean sediments: 2. Open ocean related species Palaeogeography, Palaeoclimatology, Palaeoecology 223, 66-92.

Dalsgaard, J., St. John, M., Kattner, G., Muller-Navarra, D., Hagen, W., 2003. Fatty acid and trophic markers in the pelagic marine environment. Advances in Marine Biology 46, 225-340.

Dayton, P.K. and Oliver, J.S., 1977. Antarctic Soft-Bottom Benthos in Oligotrophic and Eutrophic Environments. Science 197, 55-58.

DeMaster D. J., 2002. The accumulation and cycling of biogenic silica in the Southern Ocean: revisiting the marine silica cycle. Deep-Sea Res. II 49, 3155-3167.

Ding, H. and Sun, M.-Y., 2005. Biochemical degradation of algal fatty acids in oxic and anoxic sediment-seawater interface systems: effects of structural association and relative roles of aerobic and anaerobic bacteria. Mar. Chem. 93, 1-19.

Domack, E., Duran, D., Leventer, A., Ishman, S., Doane, S., McCallum, S., Amblas, D., Ring, J., Gilbert, R., Prentice, M., 2005. Stability of the Larsen B ice shelf on the Antarctic Peninsula during the Holocene epoch. Nature 436, 681-685.

Donegan, D. and Schrader, H., 1982. Biogenic and abiogenic components of laminated hemipelagic sediments in the central Gulf of California. Mar. Geol. 48, 215-237.

Dunstan, G.A., Volkman, J.K., Barrett, S.M., Leroi, J-M, Jeffrey, S.W., 1994. Essential polyunsaturated fatty acids from 14 species of diatom (Bacillariophyceae). Phytochemistry 35, 155-161.

Fahl, K. and Kattner, G., 1993. Lipid content and fatty acid composition of algal communities in sea-ice and water from Weddell Sea (Antarctica). Polar Biol. 13, 405-409.

Falk-Petersen, S., Sargent, J.R, Lonne, O.J., Timofeev, S., 1999. Functional biodiversity in lipids of Antarctic zooplankton: Calanoides acutus, Calanus propinquus, Thysanoessa macrura and Euphasia crystallorophias. Polar Biol. 21, 37-47.

Farrington, J.W. and Quinn, J.G., 1973. Biogeochemistry of fatty acids in recent sediments from Narragansett Bay, Rhode Island. Geochim. Cosmochim. Acta 37, 259-268.

Garrison, D.L., 1991. Antarctic sea ice biota. American Zoologist 31, 17-33.

Garrison, D.L., Buck, K.R., Fryxell, G.A., 1987. Algal assemblages in Antarctic pack ice and in ice-edge plankton. J. Phycol. 23, 564-572. 
Gille, S.T., 2002. Warming of the Southern Ocean Since the 1950s. Science 295, 1275-1277.

Grossi, V., Caradec, S., Gilbert, F., 2003. Burial and reactivity of sedimentary microalgal lipids in bioturbated Mediterranean coastal sediments. Mar. Chem. 81, 57-69.

Haddad, R.I., Martens, C.S., Farrington, J.W., 1992. Quantifying early diagenesis of fatty acids in a rapidly accumulating coastal marine sediment. Org. Geochem. 19, 205-216.

Holm-Hansen, O. and Mitchell, B.G., 1991. Spatial and temporal distribution of phytoplankton and primary production in the western Bransfield Strait region. Deep-Sea Res. 38, 961-980.

Holm-Hansen, O., Hewes, C.D., Villafañe, V.E., Helbling, E.W., Silva, N., Amos, T., 1997. Distribution of phytoplankton and nutrients in relation to different water masses in the area around Elephant Island, Antarctica. Polar Biol. 18, 145-153.

Hu, J., Zhang, H., Peng, P., 2006. Fatty acid composition of surface sediments in the subtropical Pearl River estuary and adjacent shelf, Southern China. Estuarine, Coastal and Shelf Science $66,346-356$.

Indarti, E., Abdul Majid, M.I., Hashim, R., Chong, A., 2005. Direct FAME synthesis for rapid total lipid analysis from fish oil and cod liver oil. Journal of food composition and analysis 18, 161170.

Ingólfsson, Ó., Hjort, C., Berkman, P., Björck, S., Colhoun, E., Goodwin, I.D., Hall, B., Hirakawa, K., Melles, M., Möller, P., Prentice, M., 1998. Antarctic glacial history since the Last Glacial Maximum: an overview of the record on land. Ant. Sci. 10, 326-344.

Isla, E., Sañé, E., DeMaster, D.J. Utility of ${ }^{210} \mathrm{~Pb}$ as a chronological tool for sediments off the eastern Antarctic Peninsula: the case of the continental shelf under the extinct Larsen A and B ice shelves. Unpublished results.

Kaneda, T., 1991. Iso- and anteiso-fatty acids in bacteria: biosynthesis, function and taxonomic significance. Microbiological Reviews 55, 288-302.

Karpuz, N.K. and Jansen, E., 1992. A high-resolution diatom record of the last deglaciation from the SE Norvegian Sea: documentation of rapid climatic changes. Paleoceanography 7, 499-520.

Laureillard, J.,Pinturier, L., Fillaux, J., Saliot, A., 1997. Organic geochemistry of marine sediments of the Subantarctic Indian Ocean sector: Lipid classes-sources and fate Deep Sea Res. II 44, 1085-1108.

Lee, C., 1992. Controls on organic carbon preservation: The use of stratified water bodies to compare intrinsic rates of decomposition in oxic and anoxic systems. Geochim. Cosmochim. Acta $56,3323-3335$.

Leventer, A., 1991. Sediment trap diatom assemblages from the northern Antarctic Peninsula region. Deep-Sea Res. 38, 1127-1143.

Lewis, T., Nichols, P.D., McMeekin, T.A., 2000. Evaluation of extraction method for recovery of fatty acids from lipid-producing microheterotrops. Journal of Microbiological Methods 43, 107116.

Lipps, J.H., Ronan, T.E., DeLaca, T.E., 1979. Life below the Ross Ice Shelf, Antarctica. Science 203, 447-449.

Littlepage, J.L. and Pearse, J.S., 1962. Biological and oceanographic observations under an Antarctic ice shelf. Science 137, 679-681.

Lü, D., Song, Q., Wang, X., 2010. Decomposition of algal lipids in clay-enriched marine 
511 sediment under oxic and anoxic conditions Chinese Journal of Oceanology and Limnology 28, 512 131-143.

Nahon, S., Charles, F., Lantoine, F., Vétion, G., Escoubeyrou, K., Desmalades, M., Pruski, A.M., 2010. Ultraviolet radiation negatively affects growth and food quality of the pelagic diatom Skeletonema costatum. J. Exp. Mar. Biol. Ecol. 383, 164-170.

Nichols, P.D., Palmisano, A.C., Smith, G.A., White, D.C., 1986. Lipids of the Antarctic sea ice diatom Nitzschia cylindrus. Phytochemistry 25, 1649-1653.

Nichols, D.S., Nichols, P.D., Sullivan, C.W., 1993. Fatty acid, sterol and hydrocarbon composition of Antarctic sea ice diatom communities during the spring bloom in McMurdo Sound. Antarctic Science 5, 271-278.

Parkes, R.J. and Taylor, J., 1983. The relationship between fatty acid distributions and bacterial respiratory types in contemporary marine sediments. Estuar. Coast. Shelf Sc. 16, 173-189.

Perry, G.J., Volkman, J.M., Johns, R.B., Bavor, H.J., 1979. Fatty acids of bacterial origin in contemporary marine sediments. Gechim. Cosmochim. Acta 43, 1715-1725.

Pike, J., Allen, C.S., Leventer, A., Stickley, C.E., Pudsey, C.J., 2008. Comparison of contemporary and fossil diatom assemblages from the western Antarctic Peninsula shelf. Mar. Micropal. 67, 274-287.

Reuss, N. and Poulsen, L., 2002. Evaluation of fatty acids as biomarkers for a natural bloom community. A field study of a spring bloom and a post-bloom period off West Greenland. Mar. Biol. 141, 423-434.

Riddle, M.J., Craven, M., Goldsworthy, P.M., Carsey, F., 2007. A diverse benthic assemblage $100 \mathrm{~km}$ from open water under the Amery Ice Shelf, Paleoceanography, 22. PA1204, doi:10.1029/2006PA001327.

Roberts, D., Craven, M., Minghong, C., Allison, I., Nash, G., 2007. Protists in the marine ice of the Amery Ice Shelf, East Antarctica. Polar Biol. 30, 143-153.

Rott, H., Skvarca, P., Nagler, T., 1996. Rapid collapse of northern Larsen Ice Shelf, Antarctica. Science 271.

Rützler, K. and Macintyre, I.G., 1978. Siliceous sponge spicules in coral reef sediments. Mar. Biol. 49, 147-159.

Sancetta, C., Heusser, L., Hall, M.A., 1992. Late Pliocene climate in the Southeast Atlantic: preliminary results from a multidisciplinary study of DSDP Site 532. Mar. Micropal. 20, 59-75.

Schrader, H.J., and Gersonde, R., 1978. Diatoms and silicoflagellates. In Zachariasse, W.J., et al. (Eds.), Micropaleontological Counting Methods and Techniques: An Exercise of an Eight Metres Section of the Lower Pliocene of Cap Rossello, Sicily. Utrecht Micropaleontol. Bull. 17, 129-176.

Smith, D.J., Eglinton, G., Morris, R.J., 1983. The lipid chemistry of an interfacial sediment from the Peru Continental Shelf: Fatty acids, alcohols, aliphatic ketones and hydrocarbons. Geochim. Cosmochim. Acta 47, 2225-2232.

Sañé, E., Isla, E., Grémare, A., Gutt, J., Vetion, G., DeMaster, D.J., 2011. Pigments in sediments beneath a recently collapsed ice shelves: the case of Larsen A and B shelves, Antarctic Peninsula. Journal of Sea Research, 65, 94-102.

Søreide, J.E, Falk-Petersen, Nøst Hegseth, E., Hop, H., Carroll, M.L., Hobson, K.A., Blachowiak-Samolyk, K., 2008. Seasonal feedingstrategies of Calanus in thehigh Arctic Svalbard region. Deep-Sea Res. II 55, 2225-2244. 
572 Sun, M.-Y. and Wakeham, S.G., 1994. Molecular evidence for degradation and preservation of 573 organic matter in the anoxic Black Sea Basin. Geochim Cosmochim. Acta 58, 3395-3406.

574 Sun, M.-Y., Wakeham, S.G.,Lee, C., 1997. Rates and mechanisms of fatty acid degradation in 575 oxic and anoxic coastal marine sediments of Long Island Sound, New York, USA. Geochim 576 Cosmochim. Acta 61, 341-355.

577 Tsoy, I.B., Obrezkova, M.S., Artemova, A.V., 2009. Diatoms in Surface Sediments of the Sea of 578 Okhotsk and the Northwest Pacific Ocean. Oceanology 49, 130-139.

Vaughan, D.G., Marshall, G.J., Connolley, W.M., King, J.C., Mulvaney, R., 2001. Devil in the Detail. Science 293, 1777-1779.

Venkatesan, M.I., 1988. Organic geochemistry of marine sediments in Antarctic region: marine lipids in McMurdo Sound. Org. Geochem. 12, 13-27.

Venkatesan, M. and Kaplan, I., 1987. The lipid geochemistry of Antarctic marine sediments: Bransfield Strait. Mar. Chem. 21, 347-375.

Volkman, J.K., Johns, R.B., Gillan, F.T., Perry, G.J., 1980. Microbial lipids of an intertidal sediment-I. Fatty acids and hydrocarbons. Geochim. Cosmochim. Acta 44, 1133-1143.

Volkman, J.K., Jeffrey, S.W., Nichols, P.D., Rogers, G.I., Garland, C.D., 1989. Fatty acid and lipid composition of 10 species of microalgae used in mariculture. J. Exp. Mar. Biol. Ecol. 128, 219-240.

Wakeham, S.G., 1995. Lipid biomarkers for heterotrophic alteration of suspended particulate organic matter in oxygenated and anoxic water columns of the ocean. Deep-Sea Res. I 42, 1749-1771.

Wakeham, S.G., Hedges, J.I., Lee, C., Peterson, M.L., Hernes, P.J., 1997. Compositions and transport of lipid biomarkers through the water column and surficial sediments of the equatorial Pacific Ocean. Deep-sea Res. II 44, 2131-2162.

Wright, S.W. and van den Enden, R.L., 2000. Phytoplankton community structure and stocks in the East Antarctic Marginal ice zone (BROKE survey, January-March 1996) determined by 606 CHEMTAX analysis of HPLC pigment signatures. Deep-Sea Res. II 47, 2363-2400. 
609 Table 1. Inventories and fluxes of diatom valves.

610

\begin{tabular}{ccc}
\hline \multirow{2}{*}{ Core station } & Diatom valves inventory (Diatoms $\mathbf{~ c m}^{-\mathbf{2}}$ ) & Diatom valves flux (Diatoms $\mathbf{c m}^{\mathbf{- 2}} \mathbf{\mathbf { y r } ^ { - 1 } \text { ) }}$ \\
\hline LBS & 4765774 & 9353155 \\
LBW & 4700737 & 940147 \\
LBC & 35260876 & 7052175 \\
LBN & 13045842 & 2609168 \\
LA & 25056923 & 5011385 \\
\hline
\end{tabular}

611

612

613 
614 >Sediments were studied to see if changes in the water column reflect in 615 sediments.>Sediments off the Northern and the Eastern Antarctic Peninsula were 616 compared.>2 ice shelf collapses in 1995 and 2002 affected the Eastern Antarctic 617 Peninsula.>The lability of the organic matter was higher in the Northern than in the 618 Eastern Antarctic Peninsula.>Diatom valves were deposited only after the ice shelves 619 collapses.

620

621 


\section{Figure caps}

623 Figure 1: Study area with the five sampling stations.

624 Figure 2: Diatom valves profiles in LBS, LBW, LBC, LBN and LA.

625 Figure 3: Sea ice taxa, Chaetoceros spp., F. kerguelensis, T. antarctica and non 626 dominant taxa in EAP.

627 Figure 4: Diatom (14:0 and 16:1(n-7), dinoflagellate (16:0, 18:1(n-9)cis), zooplankton $628(20: 1(n-9)$ and 22:1(n-9) and bacteria (11:0, 13:0 and 15:0) FA indicators in EAP.

629 Figure 5: PUFA, MUFA, LC-FA and MC-FA in EAP.

630 Figure 6: Chla concentration, diatom valves abundance and excess ${ }^{210} \mathrm{~Pb}$ activity in the 631 EAP region.

632

633

634 


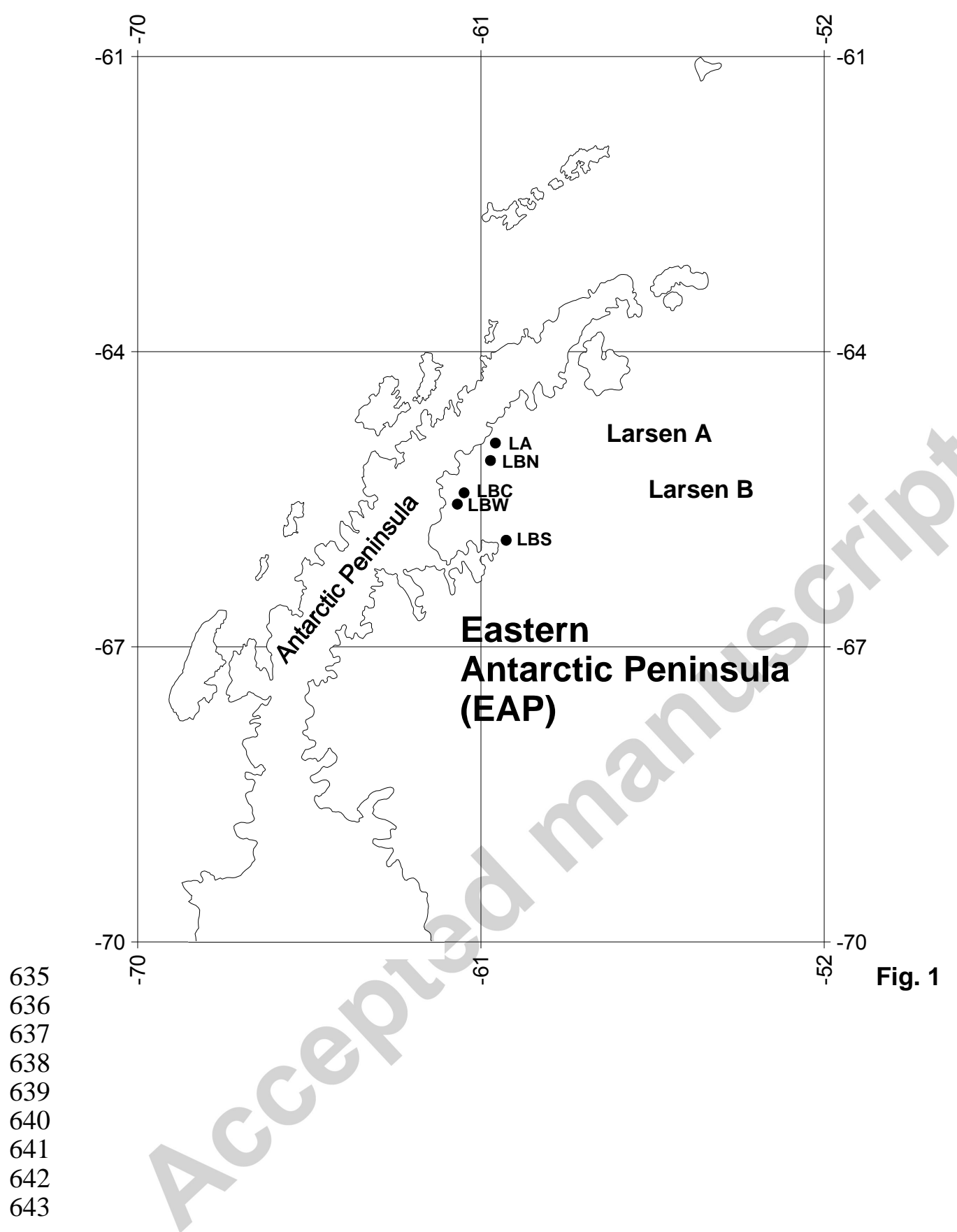



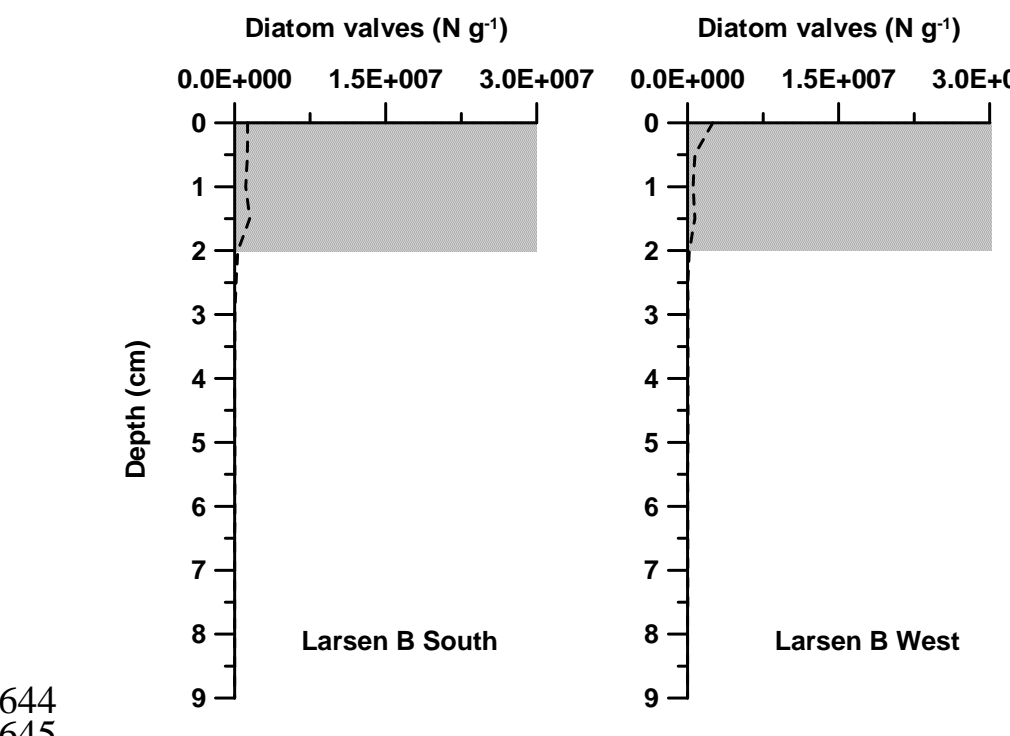

Diatom valves $\left(\mathrm{N} \mathrm{g}^{-1}\right)$

Diatom valves
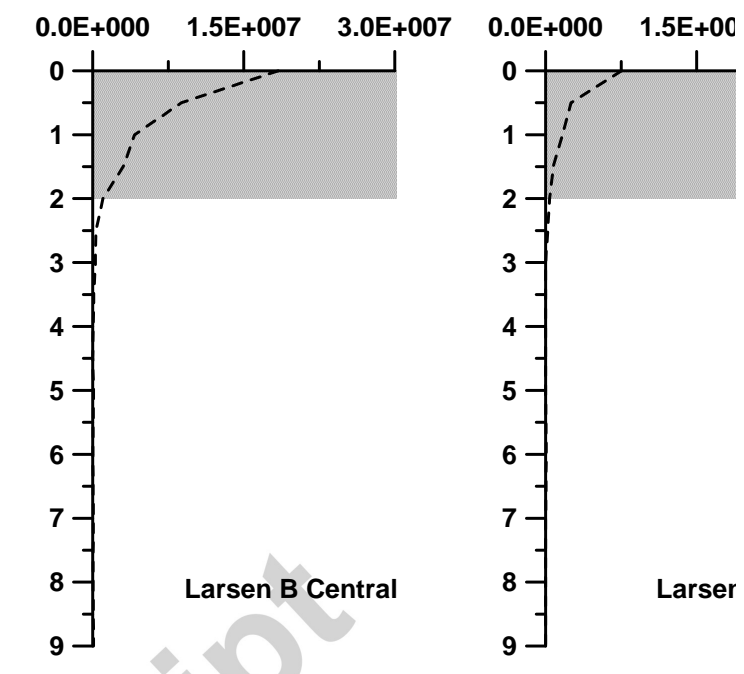

646

647

648

649

Fig. 2

651

652 


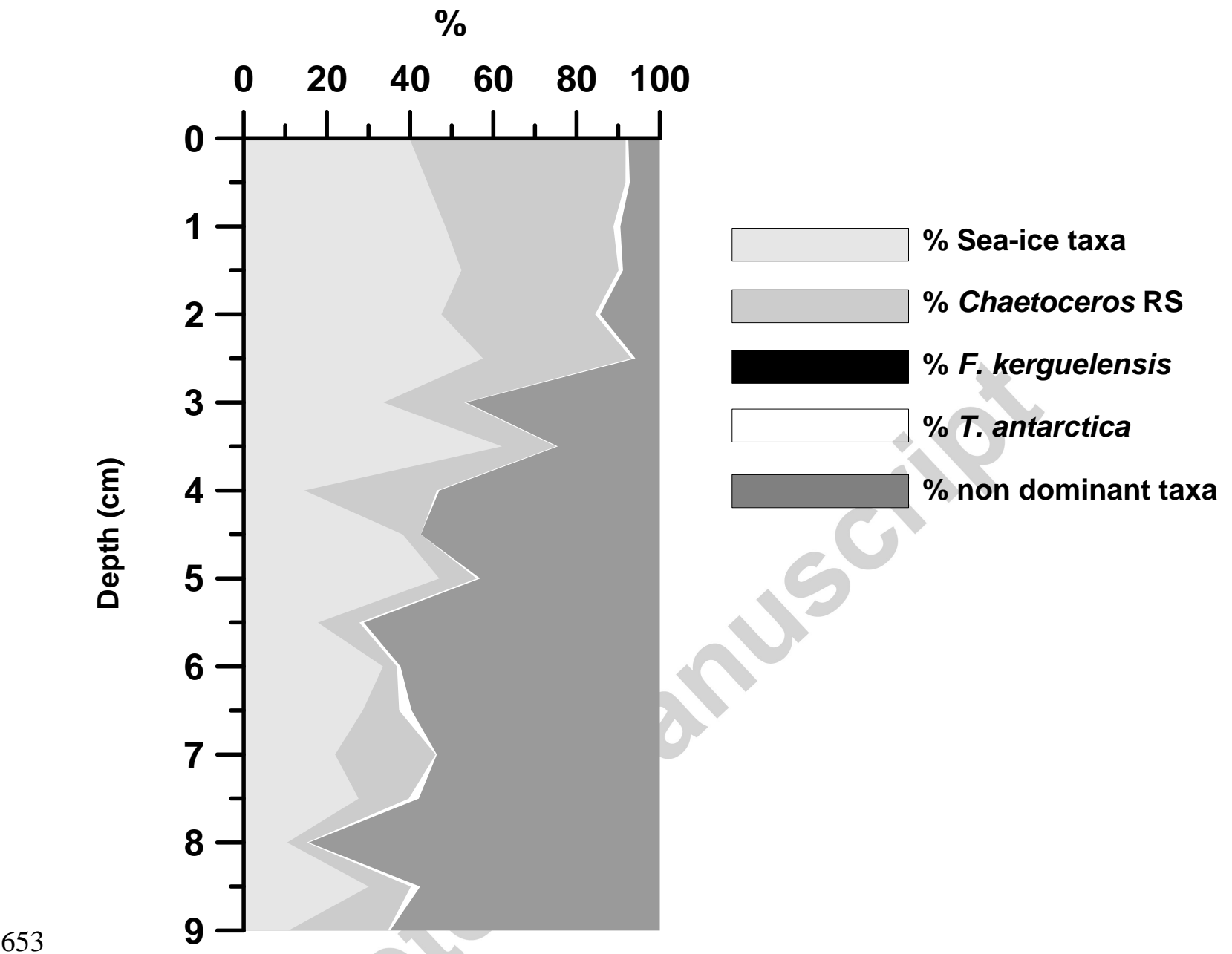

654 Fig. 3 


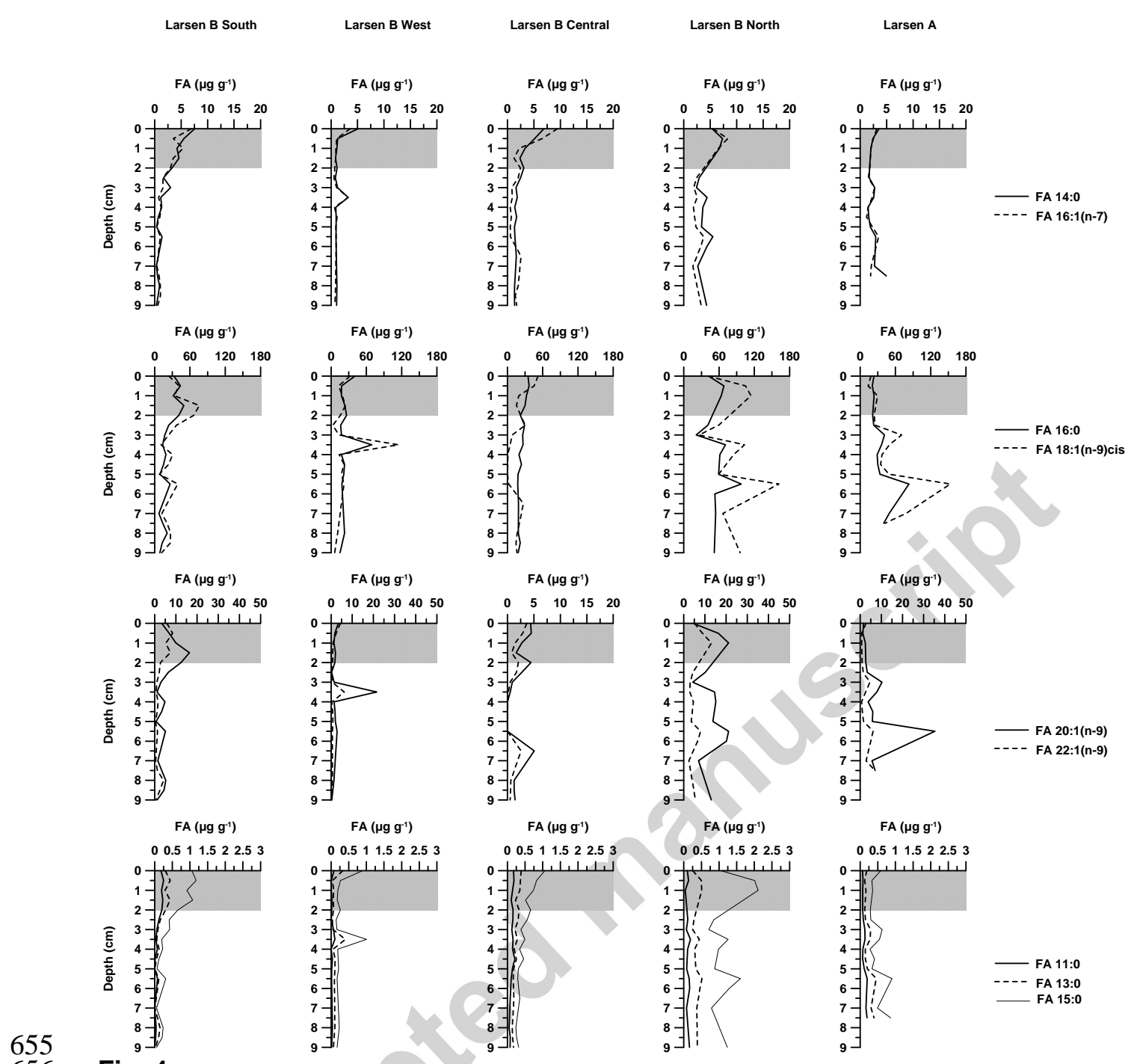




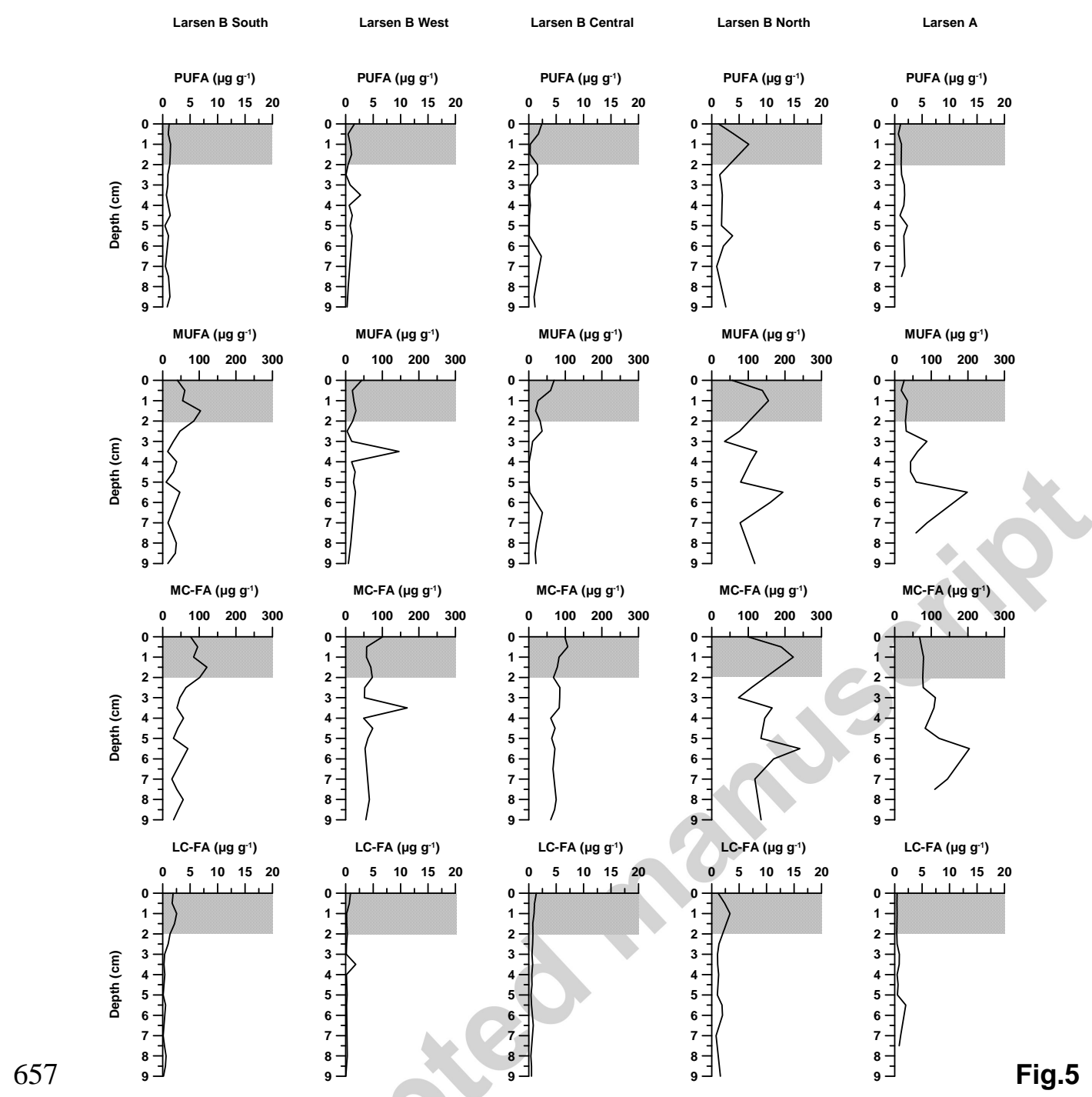




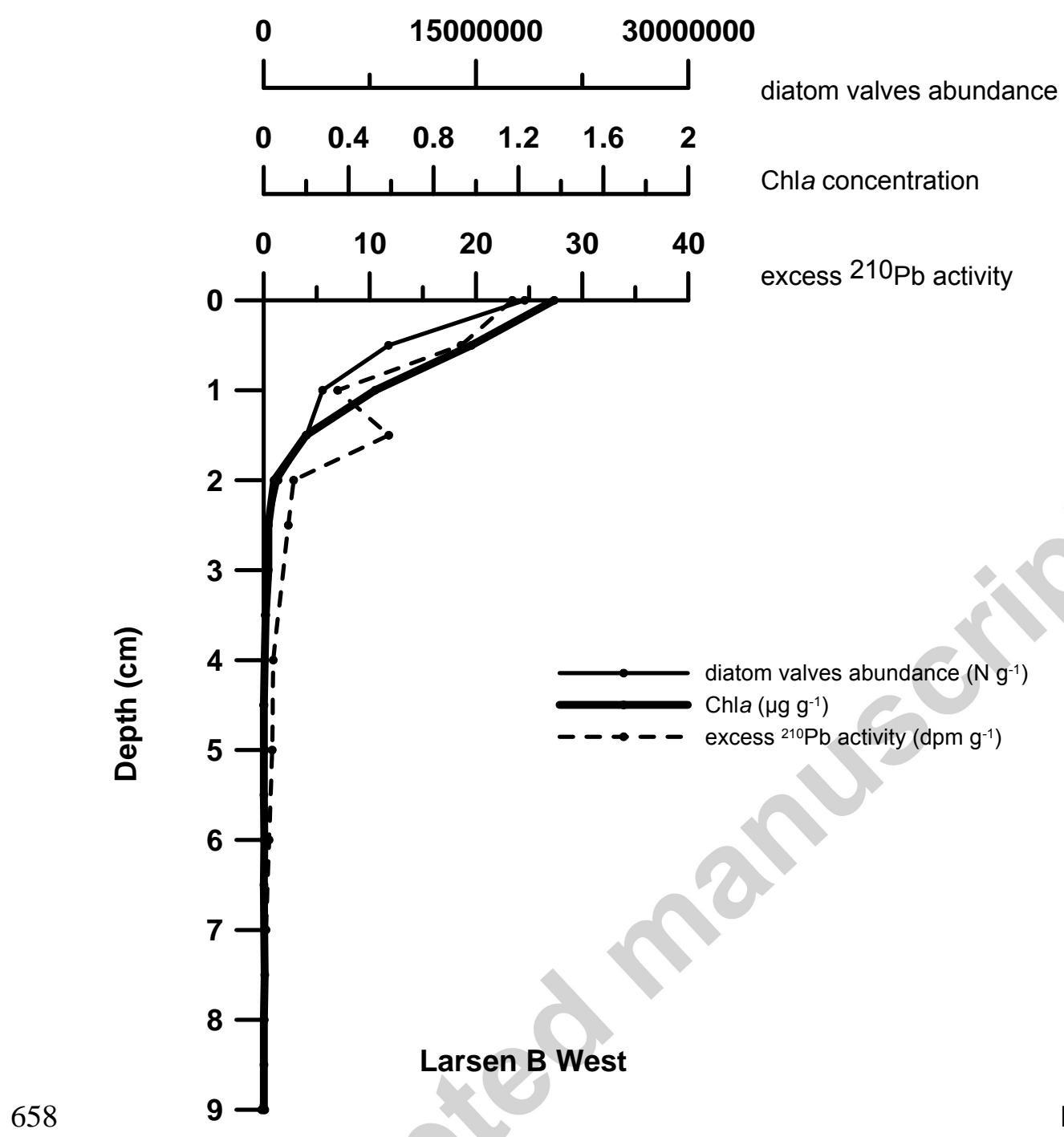

Fig. 6

659 